\title{
Cortical modulation of neuronal activity in the cat's lateral geniculate and perigeniculate nuclei: a modeling study
}

\author{
Jacek Rogala ${ }^{1 *}$, Wioletta Waleszczyk², Andrzej Wróbel ${ }^{2}$, Daniel K Wójcik ${ }^{1}$ \\ From Twentieth Annual Computational Neuroscience Meeting: CNS*2011 \\ Stockholm, Sweden. 23-28 July 2011
}

The role of cortical feedback in thalamo-cortical processing loop have been extensively investigated over the last decades. In general, these studies focused on cortical feedback exerted over lateral geniculate nucleus (LGN) principal cells, only in several cases the effects of cortical inactivation were investigated simultaneously in both thalamic relay cells and perigeniculate nucleus (PGN) inhibitory neurons. In the previous study [1] we showed in the cat that cessation of cortical input by cooling of visual cortex (areas 17 and 18) decreased spontaneous activity of LGN relay cells and increased spontaneous activity of PGN neurons. In contrast, visually evoked responses of most PGN neurons and LGN principal cells both decreased.

To identify network mechanisms underlying such functional changes we conducted a modelling study in NEURON on several networks of point neurons with varied model parameters, such as membrane properties, synaptic

Table 1 Mean spontaneous activity (spikes/s) for tested models (mean of 30 repetitions) and $\boldsymbol{t}$-test $\mathbf{P}$ values

\begin{tabular}{ccrcccrc}
\hline & \multicolumn{3}{c}{$L G N$ relay model cell } & \multicolumn{3}{c}{$P G N$ model cell } \\
\cline { 2 - 7 } $\begin{array}{c}\text { Model from } \\
\text { paper }\end{array}$ & Control & $\begin{array}{c}\text { Cortical } \\
\text { cooling }\end{array}$ & P Control & $\begin{array}{r}\text { Cortical } \\
\text { cooling }\end{array}$ \\
\hline$[2]$ & $\mathbf{1 8 . 7 3}$ & $\mathbf{1 6 . 4}$ & $\mathbf{0}$ & $\mathbf{9 . 2 7}$ & $\mathbf{1 5 . 8 3}$ & $\mathbf{0}$ \\
{$[3]$} & 25.33 & 21.27 & 0 & 8.57 & 19.77 & 0 \\
{$[4]$} & 18.97 & 20.2 & 0.14 & 6.57 & 7.93 & 0 \\
{$[5]$} & 17.73 & 20.2 & 0 & 7.93 & 7.93 & 1 \\
{$[6]$} & 20.93 & 24.97 & 0 & - & - & - \\
\hline
\end{tabular}

\footnotetext{
* Correspondence: jacek.rogala@yahoo.com
}

1 Laboratory of Neuroinformatics, Dept. of Neurophysiology, Nencki Institute, 02-093 Warsaw, Poland

Full list of author information is available at the end of the article weights and axonal delays. We considered five network topologies of the retino-geniculo-cortical pathway [2-6].

All models were robust against changes of axonal delays except for delay between LGN feed-forward

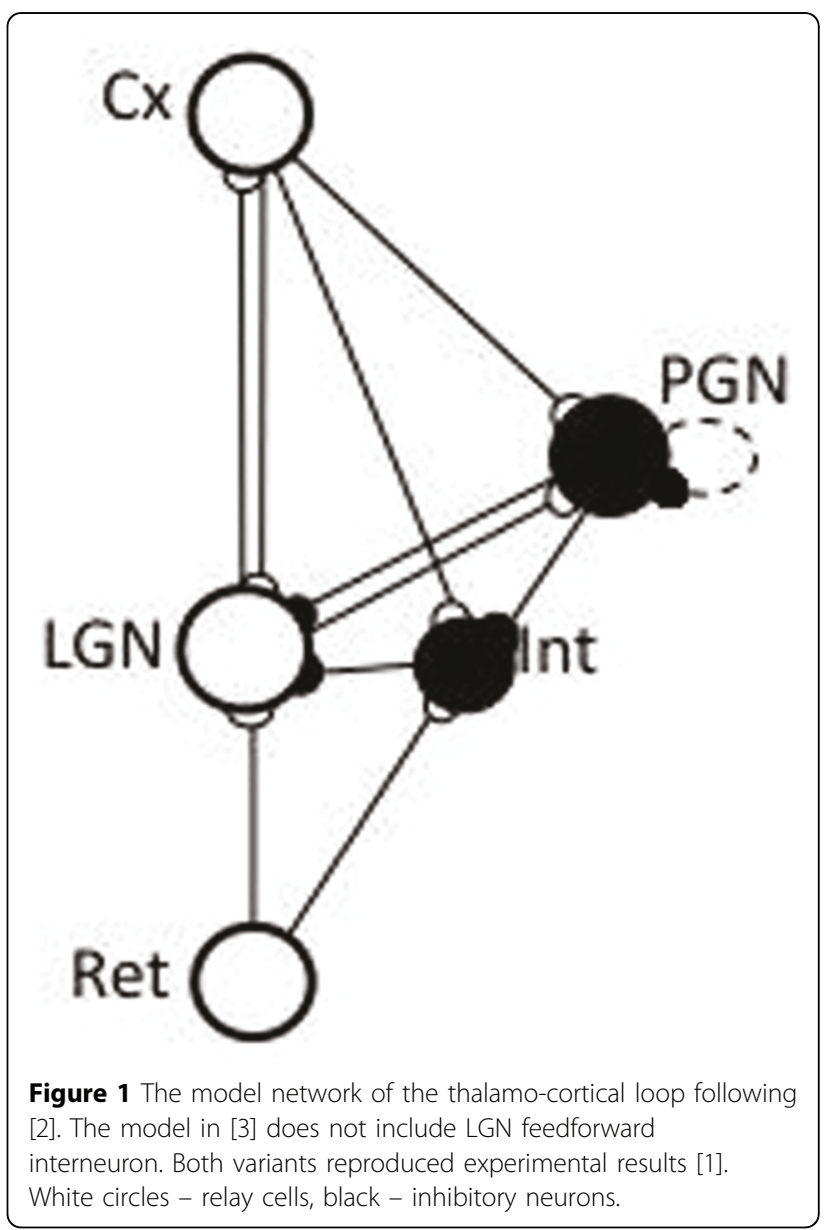


interneuron and principal cell when this connection was present. In all such cases the models were found to be very sensitive to this delay. To reproduce the experimental results [1] the models required: 1) reciprocally connected PGN cells, connection present only in two model variants $[2,3]$, and 2) slow decay of intracellular calcium. We found model [2] most consistent with known physiology and anatomy of the cat. Table 1. Figure 1.

\section{Author details}

'Laboratory of Neuroinformatics, Dept. of Neurophysiology, Nencki Institute, 02-093 Warsaw, Poland. 'Laboratory of the Visual System, Dept. of

Neurophysiology, Nencki Institute, 02-093 Warsaw, Poland.

Published: 18 July 2011

\section{References}

1. Waleszczyk WJ, Bekisz M, Wróbel A: Cortical modulation of neuronal activity in the cat's lateral geniculate and perigeniculate nuclei. Experimental neurology 2005, 196(1):54-72.

2. Ahlsen G, Lindstrom S, Lo FS: Interaction between inhibitory pathways to principal cells in the lateral geniculate nucleus of the cat. Experimental Brain Research 1985, 58:134-143.

3. Huguenard J, McCormick DA: Thalamic synchrony and dynamic regulation of global forebrain oscillations. Trends in Neurosciences 2007, 30(7):350-6.

4. Einevoll GT, Plesser HE: Linear mechanistic models for the dorsal lateral geniculate nucleus of cat probed using drifting-grating stimuli. Network 2002, 13(4):503-30.

5. Hillenbrand U, van Hemmen JL: Does corticothalamic feedback control cortical velocity tuning? Neural computation 2001, 13(2):327-55.

6. Wörgötter F, Nelle E, Li B, Funke K: The influence of corticofugal feedback on the temporal structure of visual responses of cat thalamic relay cells. Journal of Physiology 1998, 509:797-815.

doi:10.1186/1471-2202-12-S1-P373

Cite this article as: Rogala et al:: Cortical modulation of neuronal activity in the cat's lateral geniculate and perigeniculate nuclei: a modeling study. BMC Neuroscience 2011 12(Suppl 1):P373.

\section{Submit your next manuscript to BioMed Central and take full advantage of:}

- Convenient online submission

- Thorough peer review

- No space constraints or color figure charges

- Immediate publication on acceptance

- Inclusion in PubMed, CAS, Scopus and Google Scholar

- Research which is freely available for redistribution

Submit your manuscript at www.biomedcentral.com/submit
C Biomed Central 